\title{
SEASONAL VARIATIONS IN HYDROGEN PEROXIDE IN POLAR ICE CORES
}

\author{
by
}

Andreas Sigg and Albrecht Neftel

(Universität Bern, Physikalisches Institut, $\mathrm{CH}-3012$ Bern, Sidlerstraße 5, Switzerland)

\begin{abstract}
Hydrogen peroxide is present in polar snow and ice in remarkably high concentrations. With values up to $300 \mathrm{ppb}$, $\mathrm{H}_{2} \mathrm{O}_{2}$ is one of the most concentrated impurities in polar ice. We present a continuous $\mathrm{H}_{2} \mathrm{O}_{2}$ firn record from Siple Station (Antarctica); it covers the last 83 years with a resolution of 10-20 samples per year. A very strong seasonality is present in this record. This seasonality is also observed in a Greenland ice core from Dye 3, where we have continuously measured the top $10 \mathrm{~m}$ with the same resolution. The maximum concentrations correspond to summer snow layers and can exceed winter snow concentrations by a factor of 10 . This property makes $\mathrm{H}_{2} \mathrm{O}_{2}$ a useful tracer for dating suitable cores by counting annual layers. The different steps needed to relate the atmospheric to the ice-core $\mathrm{H}_{2} \mathrm{O}_{2}$ concentration are discussed. As with isotopic tracers, diffusion in the firn smooths the original $\mathrm{H}_{2} \mathrm{O}_{2}$ concentration profile.
\end{abstract}

\section{INTRODUCTION}

More than 100 years ago, Schöne (1874) found that $\mathrm{H}_{2} \mathrm{O}_{2}$ is present in hoar frost. Nevertheless, only during the past few years has it been appreciated that $\mathrm{H}_{2} \mathrm{O}_{2}$ is one of the most important species in atmospheric chemistry. Because of its intermediate position between extreme reactive species such as $\mathrm{OH}$ or $\mathrm{HO}_{2}$ radicals and the long-living species, it is a useful tool for testing atmospheric-chemistry model calculations. Reliable measurements of the atmospheric concentrations have existed only for a few years. Because of the reactivity of $\mathrm{H}_{2} \mathrm{O}_{2}$ in the liquid phase and its high solubility, it is used up quickly in clouds over mid-latitudes (Kelly and others 1985) and the interpretation of the measured data in precipitation samples is extremely difficult. In 1984 it was realized that $\mathrm{H}_{2} \mathrm{O}_{2}$ is present in relatively large amounts in polar snow and ice samples (Neftel and others 1984). It is quite astonishing that hydrogen peroxide, a rather unstable and reactive species, survives the firnification process and is still detectable in ice several thousand years old. The observed long-term trend in Greenland deep ice cores points to a very slow disintegration of $\mathrm{H}_{2} \mathrm{O}_{2}$ with a half-life of the order of several thousand years (Neftel and others 1986). The suppressed chemical reactivity in snow which is well below the freezing point and the ease with which $\mathrm{H}_{2} \mathrm{O}_{2}$ is built into the ice matrix favour the preservation of records of $\mathrm{H}_{2} \mathrm{O}_{2}$ in the polar ice sheets. It seems, therefore, that the polar precipitation archives could be used to trace back in time the atmospheric $\mathrm{H}_{2} \mathrm{O}_{2}$ for high latitudes, if the transfer function from the atmospheric concentration to the ice concentration is fully understood.

In this paper we present two continuous $\mathrm{H}_{2} \mathrm{O}_{2}$ measuring series: from Siple Station, West Antarctica, covering the last 83 years, and from Dye 3 , south Greenland, covering the last 10 years. The different steps required to evaluate the atmospheric concentration from the measured ice data are discussed.

\section{MEASURING TECHNIQUE}

The data presented in this paper are based on discrete samples. The samples are cut with a band saw to give a cross-section of about $2 \mathrm{~cm}^{2}$. The sample length is chosen according to the desired vertical resolution. Saw-dust is removed as far as possible, with a Teflon brush. The samples are put into polyacrylic vessels and melted in a moderately warm-water bath. Immediately after melting, aliquots of these samples are inserted into the measuring system. It is important to keep the time between melting and measurement as short as possible, because $\mathrm{H}_{2} \mathrm{O}_{2}$ tends to decay in aqueous solutions. Typical values are $1-5 \%$ in $15 \mathrm{~min}$.

We have two independent systems to measure $\mathrm{H}_{2} \mathrm{O}_{2}$ concentrations in aqueous solutions at the ppb $(=\mu \mathrm{g} / \mathrm{kg})$ level. Both methods are fast and need only about $200 \mu \mathrm{l}$ of sample per measurement.

The first method is based on the chemiluminescent reaction of hydrogen peroxide with TCPO, i.e. bis(2,4,6-trichlorophenyl) oxalate (Klockow and Jacob 1986). The emitted light during the reaction is proportional to the $\mathrm{H}_{2} \mathrm{O}_{2}$ concentration. The solubility of TCPO in water is insufficient; therefore this reagent has to be dissolved in acetone. Perylene is used as a fluorescer. It can be added to the acetone solution. Because the reaction is $\mathrm{pH}$-dependent, the samples have to be adjusted to $\mathrm{pH}=7.8$ with a borate buffer solution.

In the second method, called the enzymatic method, hydrogen peroxide reacts with 4-ethylphenol and builds dimers of this compound quantitatively. This reaction needs the presence of the enzyme peroxidase. The concentration of this dimer is proportional to the $\mathrm{H}_{2} \mathrm{O}_{2}$ concentration and can be determined fluorometrically. Addition of borate buffer is necessary also in this method. A similar method is described in Lazrus and others (1985).

The two systems are presented schematically in Figure 1. Sample input is exactly the same for both devices. The input tube is moved from sample to sample while the peristaltic pump is running. The sampling time is about half a minute. While the tube is moved, an air segment is inserted automatically between two sample segments. This air bubble is necessary to separate the samples. Without these air segments, mixing in the thin tubes would be stronger. Ten samples are measured in one series between two blanks. The blank water is bi-distilled and a platinum-coated catalyst in the water container removes any remaining $\mathrm{H}_{2} \mathrm{O}_{2}$. From time to time, the systems have to be calibrated with standard solutions, diluted from a $1 \% 0 \mathrm{H}_{2} \mathrm{O}_{2}$ stock solution. This stock solution is more stable than the diluted standards, but at least every month it has to be calibrated by titration with $\mathrm{KMnO}_{4}$.

Both methods need only small samples, and are fast and very sensitive; both methods, however, exhibit interferences with other trace species:

The enzymatic method is sensitive to organic peroxides, such as methylhydroperoxide and peroxyacetic acid, too (Lazrus and others 1985). This interference can be eliminated: the enzyme catalase destroys $\mathrm{H}_{2} \mathrm{O}_{2}$ much faster than other peroxides. The presence of organic peroxides can therefore be tested by adding catalase to the sample before measurement. Until now, we have never found organic peroxides in polar ice. 
a) peristaltic pump glass spiral photomultiplier

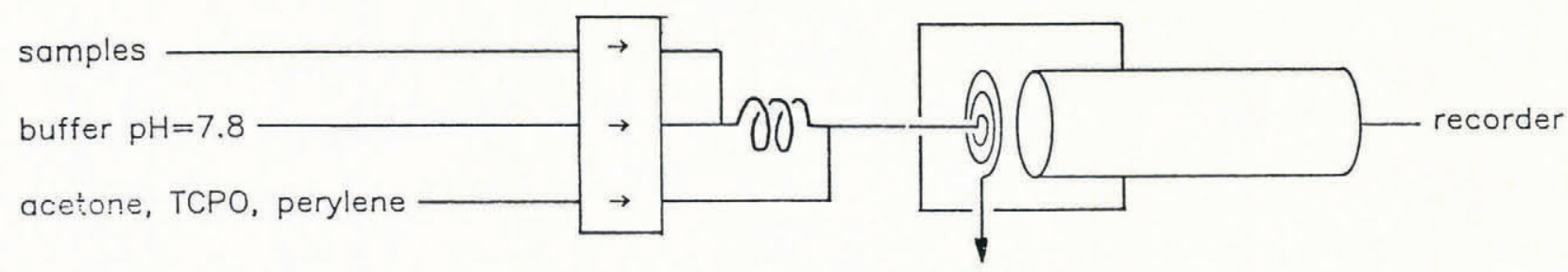

b)

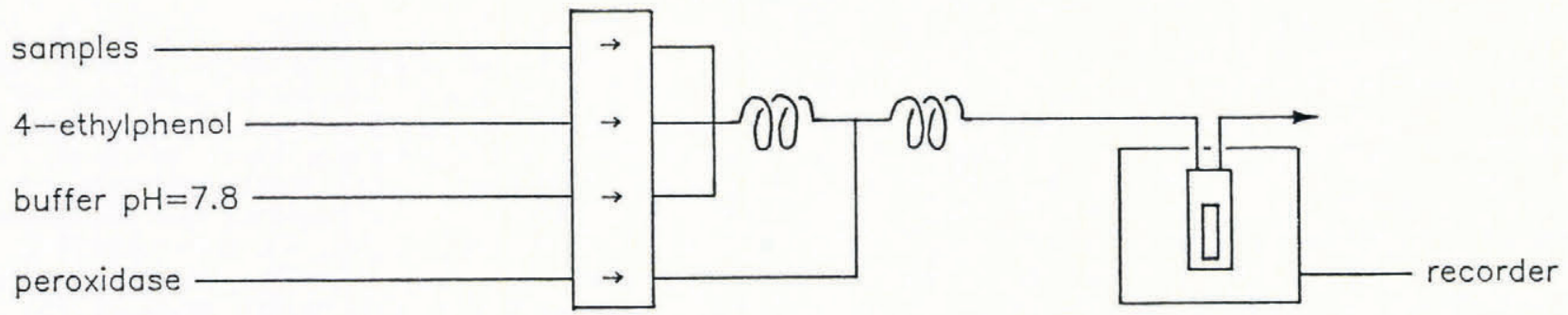

Fig.1. Measuring systems: (a) Chemiluminscent method; (b) Enzymatic method.

On the other hand, the chemiluminscent method is much less sensitive to organic peroxides, but another interference leads to problems with this method: the sensitivity to $\mathrm{Fe}^{2+}$ is comparable to that for $\mathrm{H}_{2} \mathrm{O}_{2}$ (Jacob unpublished). This would be a minor problem if we had clean samples, because the $\mathrm{Fe}^{2+}$ content of polar ice is certainly well below the $\mathrm{H}_{2} \mathrm{O}_{2}$ content. But when the samples are cut with a band saw, traces of iron may contaminate the sample.

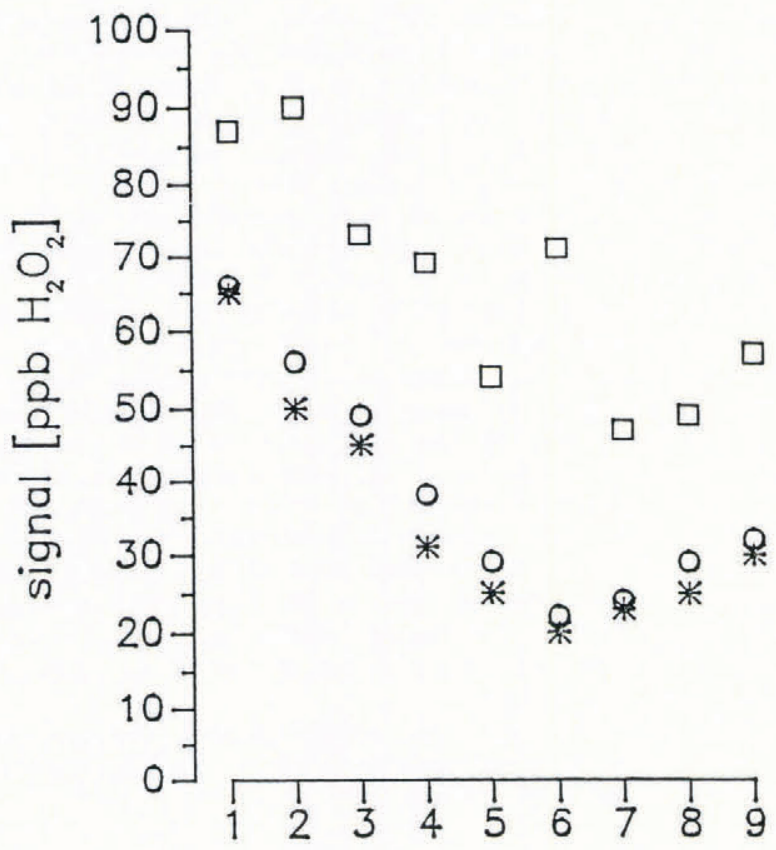

\section{sample number}

Fig.2. Interference of the chemiluminescent method: contamination with $\mathrm{Fe}(\mathrm{II})$. Squares: chemiluminescent method (total signal); circles: fluorometric method; stars: chemiluminescent method $\left(\mathrm{H}_{2} \mathrm{O}_{2}\right.$ signal).
That this problem really exists, is demonstrated in Figure 2. The chemiluminescent method leads sometimes to much higher concentrations than the enzymatic method. If catalase is added, a high residual signal is still found. The difference between the original chemiluminescent signal and this residual signal corresponds to $\mathrm{H}_{2} \mathrm{O}_{2}$ only. The $\mathrm{H}_{2} \mathrm{O}_{2}$ concentration determined in this way is in good agreement with the enzymatic measurement. Differences between the two methods were always observed after replacing the saw blade. Therefore the connection between this phenomenon and contamination by the new saw blade is obvious. This problem could be solved by measuring routinely both the total chemiluminescent signal and the residual signal after destroying $\mathrm{H}_{2} \mathrm{O}_{2}$ with catalase. But the enzymatic method offers some other practical advantages, especially for in-situ measurements: first, the calibration of the system is very stable, because all reagents are present in abundance and an equilibrium concentration after the reaction is measured. The calibration therefore does not depend on the exact reagent concentrations or the pump velocity. Secondly, no acetone is needed and all reagents are soluble in water.

\section{RESULTS FROM SIPLE AND DYE 3}

During summer $1983-84$, a $200 \mathrm{~m}$ core was drilled at Siple Station (Antarctica) by the Polar Ice Coring Office. Siple Station combines a high accumulation rate of $50 \mathrm{~cm}$ ice equivalent with an annual mean temperature of $-24^{\circ} \mathrm{C}$. This is very advantageous for investigations of seasonally varying parameters. The almost complete absence of melt layers is a great advantage of this site for many investigations.

Figure 3a shows the $\mathrm{H}_{2} \mathrm{O}_{2}$ record of the top $64 \mathrm{~m}$ of the Siple core. The sample resolution is $5 \mathrm{~cm}$, corresponding to about $10-20$ samples per year. It is remarkable how little noise is present in the $\mathrm{H}_{2} \mathrm{O}_{2}$ signal. The seasonal signal is very strong and is still present at the lower end of the record, which corresponds approximately to the firn-ice transition. That these wiggles really represent seasonal cycles is confirmed by the fact that independent dating of this core by $\mathrm{H}_{2} \mathrm{O}_{2}$ and electrical conductivity measurements (Schwander unpublished) lead to exactly the same result. The electrical conductivity method (ECM) dating by counting annual layers is supported by absolute time marks, provided by historically known volcanic events. 


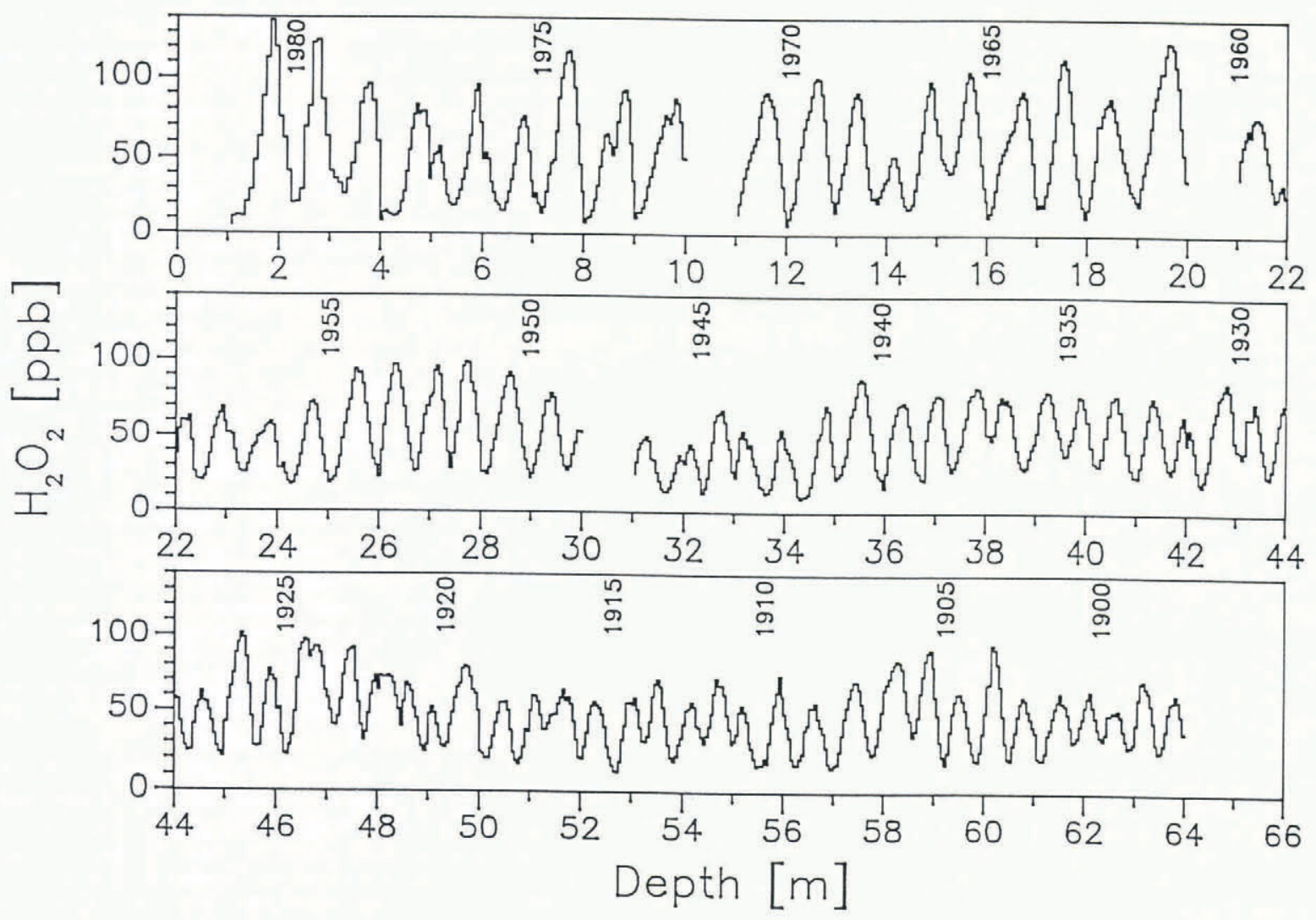

Fig.3. (a) The Siple Station $\mathrm{H}_{2} \mathrm{O}_{2}$ record.

An interesting point is the relation between the seasonal parameters $\mathrm{H}_{2} \mathrm{O}_{2}$ and $\delta^{18} \mathrm{O}$. Unfortunately, no $\delta^{18} \mathrm{O}$ measurements on this core segment have been made yet. However, parallel measurements of these parameters in deeper pieces of the same core show that $\mathrm{H}_{2} \mathrm{O}_{2}$ maxima coincide more or less with $\delta^{18} \mathrm{O}$ maxima. Nevertheless, more measurements are necessary to determine the exact phase relationship between $\mathrm{H}_{2} \mathrm{O}_{2}$ and $\delta^{18} \mathrm{O}$.
A strong seasonality of $\mathrm{H}_{2} \mathrm{O}_{2}$ does not only exist in Antarctic ice. Measurements on the top $10 \mathrm{~m}$ of a $300 \mathrm{~m}$ core from Dye 3, drilled in summer 1986, show a similar picture. Dye 3, located in southern Greenland, has about the same accumulation rate as Siple Station, but a higher annual mean temperature of $-19.6{ }^{\circ} \mathrm{C}$. The occurrence of melting in summer is normal. In Figure 4 the $\mathrm{H}_{2} \mathrm{O}_{2}$ profile of the top $10 \mathrm{~m}$ is plotted, together with the $\delta^{18} \mathrm{O}$

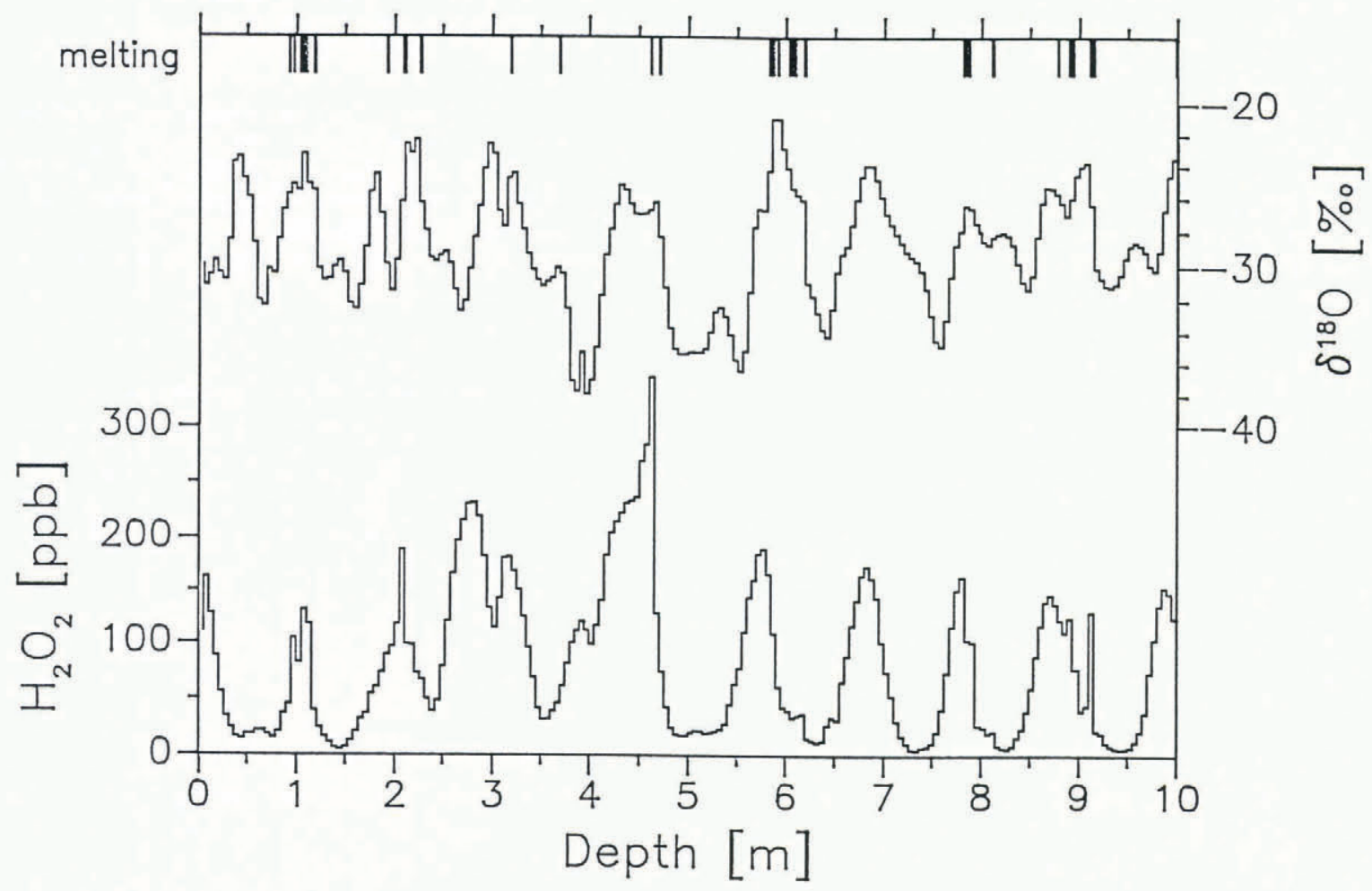

Fig.4. Dye 3: comparison of $\mathrm{H}_{2} \mathrm{O}_{2}$ with $\delta^{18} \mathrm{O}$. 
profile. The resolution is $5 \mathrm{~cm}$ or about 20 samples per year. The variability of the $\mathrm{H}_{2} \mathrm{O}_{2}$ concentration is even greater than in the Siple Station core and the concentration level is higher. Comparison with the $\delta^{18} \mathrm{O}$ record shows that there is a small phase lag between the two parameters. $\mathrm{H}_{2} \mathrm{O}_{2}$ seems to be shifted to the left, i.e. $\mathrm{H}_{2} \mathrm{O}_{2}$ maxima are later than $\delta^{18} \mathrm{O}$ maxima.

\section{DISCUSSION}

Hydrogen peroxide is of interest in atmospheric chemistry. First, $\mathrm{H}_{2} \mathrm{O}_{2}$ is believed to be the most efficient oxidizer for dissolved $\mathrm{SO}_{2}$ in cloud droplets with $\mathrm{pH}$ lower than 5 (Penkett and others 1979). Secondly, $\mathrm{H}_{2} \mathrm{O}_{2}$ is involved in tropospheric photochemistry. It acts as a major sink for $\mathrm{HO}_{2}$ radicals which are members of the odd hydrogen cycle (Logan and others 1981).

If we want to translate our ice-core data into atmospheric $\mathrm{H}_{2} \mathrm{O}_{2}$ concentrations, we have to investigate mainly two processes: the scavenging mechanism of $\mathrm{H}_{2} \mathrm{O}_{2}$ from the atmosphere to the snow, and the influence of firnification and of summer melting.

\section{Condensation of $\mathrm{H}_{2} \mathrm{O}_{2}$ during precipitation}

The initial stage from the atmosphere to the ice core is the formation of snow in the atmosphere. Growth of snow crystals out of the gas phase is the most probable process in polar regions. We therefore neglect the presence of supercooled water droplets, particularly the aggregation of these droplets on to snow crystals (riming). According to Jacob (unpublished), our conception about the condensation process is very simple: $\mathrm{H}_{2} \mathrm{O}_{2}$ is supposed to behave like water vapour, i.e.

$$
\left[\frac{\mathrm{c}\left(\mathrm{H}_{2} \mathrm{O}_{2}\right)}{\mathrm{c}\left(\mathrm{H}_{2} \mathrm{O}\right)}\right]_{\text {atmosphere }}=\left[\frac{\mathrm{c}\left(\mathrm{H}_{2} \mathrm{O}_{2}\right)}{\mathrm{c}\left(\mathrm{H}_{2} \mathrm{O}\right)}\right]_{\text {snow }}
$$

We call this equation the co-condensation model. The idea is the following: $\mathrm{H}_{2} \mathrm{O}_{2}$ has a freezing point very similar to that of water $\left(-0.41^{\circ} \mathrm{C}\right.$ at 1 atmosphere) and is easily built into the ice matrix (see below). If the sticking probabilities of gaseous $\mathrm{H}_{2} \mathrm{O}_{2}$ and $\mathrm{H}_{2} \mathrm{O}$ on a growing ice surface are similar, we do not expect a fractionation between $\mathrm{H}_{2} \mathrm{O}_{2}$ and $\mathrm{H}_{2} \mathrm{O}$.

We have evidence from experiments that co-condensation is a reasonable model for the incorporation of $\mathrm{H}_{2} \mathrm{O}_{2}$ into snow. It is actually possible to measure $\mathrm{H}_{2} \mathrm{O}_{2}$ gas-phase concentrations by a cryogenic technique (Jacob and others 1986). In this method, the air is pulled through a cooled glass cylinder; the water vapour freezes on the cold surface and with it the $\mathrm{H}_{2} \mathrm{O}_{2}$ vapour. Jacob checked a possible fractionation, using a cold trap (after the glass cylinder) which removed all remaining water and $\mathrm{H}_{2} \mathrm{O}_{2}$; there was no difference between the $\mathrm{H}_{2} \mathrm{O}_{2}$ concentrations in the cylinder and in the cold trap. This means that one can determine the gas-phase $\mathrm{H}_{2} \mathrm{O}_{2}$ concentration by this method, if the absolute air humidity is known. In another experiment, test gas with known $\mathrm{H}_{2} \mathrm{O}_{2}$ concentration and humidity was generated, and $\mathrm{H}_{2} \mathrm{O}_{2}$ was measured using the cryogenic method. The measured concentration was close to the expected value.

We successfully applied the cryogenic method at Dye 3 during June 1986. We have performed 40 gas-phase measurements, about ten of them during or immediately after precipitation events. We also monitored the surfacesnow $\mathrm{H}_{2} \mathrm{O}_{2}$ concentration and found that, within $20 \%$ error, the frozen air humidity exhibited the same concentration as the freshly fallen snow. The concentrations of $170-300 \mathrm{ppb}$ fit well with the summer $\mathrm{H}_{2} \mathrm{O}_{2}$ level of the core (Fig.4). During sunny periods, however, the cryogenic technique generally led to higher concentrations in the condensed water vapour, between 400 and $800 \mathrm{ppb}$. The gas-phase $\mathrm{H}_{2} \mathrm{O}_{2}$ concentrations were calculated using the measured water-vapour pressure. They ranged from 0.4 to $1.5 \mathrm{ppb}$ volume. These values agree well with mode calculations. Hov and Isaksen (in press) calculate a $\mathrm{H}_{2} \mathrm{O}_{2}$ concentration of about $0.3 \mathrm{ppb}$ volume for Dye 3 at the end of May. Logan and others (1981) predict about $0.8 \mathrm{ppb}$ volume for this location in summer conditions.

An important feature of co-condensation is the influence of water-vapour concentration. Consequently, the air temperature of snow formation has a strong influence on the relation between atmospheric and snow $\mathrm{H}_{2} \mathrm{O}_{2}$ concentration. The saturation water-vapour pressure of ice decreases by at least a factor of 10 when temperature decreases $25^{\circ} \mathrm{C}$. This temperature range is a lower limit for the variations between summer and winter at Siple Station and Dye 3. Thus a constant gas-phase $\mathrm{H}_{2} \mathrm{O}_{2}$ concentration would produce snow concentrations ten times higher in winter than in summer. However, the measured summer-snow $\mathrm{H}_{2} \mathrm{O}_{2}$ concentration is about five to ten times higher than that of winter snow. Taking into account this temperature effect of co-condensation, we end up with an atmospheric $\mathrm{H}_{2} \mathrm{O}_{2}$ summer-to-winter ratio of at least 50 . This does not contradict model calculations. The two global tropospheric chemistry models mentioned (Hov and Isaksen, in press, and Logan and others 1981) predict strong meridional $\mathrm{H}_{2} \mathrm{O}_{2}$ gradients, from high values in low latitudes to low values in polar regions. The drop to low concentrations is very pronounced in the winter hemisphere. This is a consequence of the missing sunlight, which is necessary for the production of the precursors of atmospheric $\mathrm{H}_{2} \mathrm{O}_{2}$. Quantitative statements are difficult, because polar locations represent marginal regions in the models, but Logan's model suggests that summer-to-winter ratios of 50 are not unreasonable.

\section{Firnification}

The annual mean concentrations of the Siple Station record exhibit some variations, but no decreasing trend with depth (Fig. 3b). Therefore we assume that the firnification process smooths the initial $\mathrm{H}_{2} \mathrm{O}_{2}$ distribution, but does not affect the mean concentrations.

Smoothing of a signal in the firn due to evaporation,

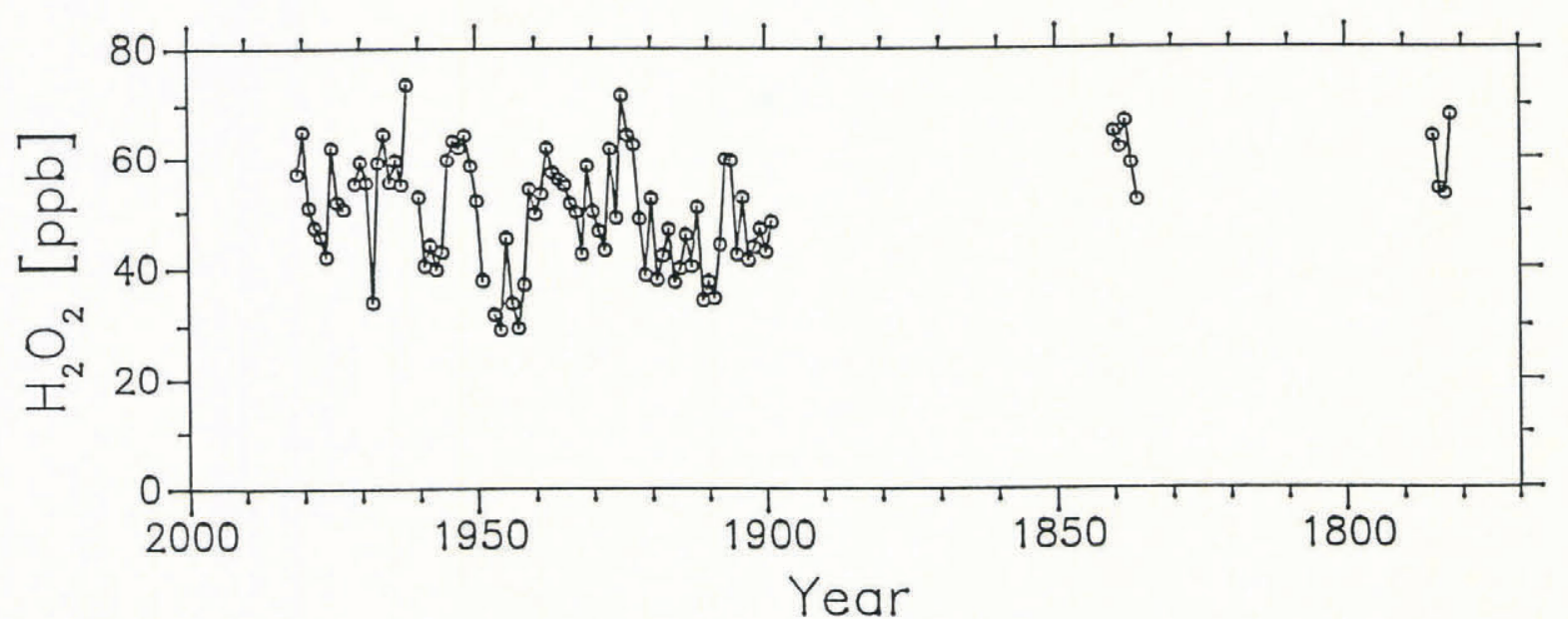

Fig.3b. The Siple Station $\mathrm{H}_{2} \mathrm{O}_{2}$ record. Annual mean values. 
gas diffusion and recondensation is typical for "water-related" components like hydrogen and oxygen isotopes. $\mathrm{H}_{2} \mathrm{O}_{2}$ is the first chemical impurity in which a similar smoothing can be observed. We have tried to reconstruct the original $\mathrm{H}_{2} \mathrm{O}_{2}$ signal in a similar way to Johnsen (1977). Diffusion is most effective in the upper firn, due to high porosity and temperature variations (Whillans and Grootes 1985). For the following calculation we therefore assume that diffusion is limited to the upper firn. Then we can reconstruct the original signal for the lower firn. The effect of diffusion on a given isotope or $\mathrm{H}_{2} \mathrm{O}_{2}$ signal $x(z), z$ being the depth, can be described in the frequency domain by a Gaussian low-pass filter $F(k)$, $k$ being the wave number. If $x(z)$ is the original signal, $y(z)$ the diffused signal and $\mathrm{X}(\mathrm{k})$ and $\mathrm{Y}(\mathrm{k})$ their Fourier transforms:

$$
\begin{aligned}
& Y(k)=F(k) X(k) \\
& F(k)=\exp \left(-\frac{1}{2} k^{2} L^{2}\right) \\
& k=2 \pi / \lambda
\end{aligned}
$$

$\lambda$ is the wavelength and $\mathrm{L}$ the (empirical) diffusion length. We adopt from Johnsen (1977) a value $\mathrm{L}=8 \mathrm{~cm}$ of ice. The reconstruction of $x(z)$ requires the inversion of the filter $F(k)$. To avoid the blow-up of high-frequency noise, we take the filter $G(k)$ instead of $F^{-1}(k)$ :

$$
G=\frac{F^{*}\left(1+\varepsilon^{2}\right)}{|F|^{2}+\varepsilon^{2}}
$$

$\varepsilon$ determines the degree of low-pass filtering. The result of this reconstitution is shown in Figure 5 , calculated with $\varepsilon=$ 0.15 . Further calculations showed that a smaller $\varepsilon$ increases the high-frequency noise, but does not affect the annual signal substantially. It is clear that this calculation should not be over-interpreted, but the reconstituted signal at least shows a variability similar to the uppermost, only weakly diffused, annual cycles, and the minima are still always positive. That means that the diffusion length of $8 \mathrm{~cm}$ is a reasonable value for diffusion in the firn not only for $\delta^{18} \mathrm{O}$, but also for $\mathrm{H}_{2} \mathrm{O}_{2}$.

\section{Influence of melt layers}

Melting has an incalculable influence on a chemical impurity concentration, especially if there is an interaction with the gas phase. The melt layers in our Dye 3 record are indicated in Figure 4. Many of these melt layers seem not to affect the $\mathrm{H}_{2} \mathrm{O}_{2}$ profile, but there are thin, high $\mathrm{H}_{2} \mathrm{O}_{2}$ concentration peaks which all coincide with melt layers. Surface melting can therefore influence the $\mathrm{H}_{2} \mathrm{O}_{2}$ concentration strongly. This is not surprising, because $\mathrm{H}_{2} \mathrm{O}_{2}$ has a very high Henry constant $K_{H}$. At the freezing point, the value of $\mathrm{K}_{\mathrm{H}}$ is $5.7 \times 10^{5} \mathrm{~mol} / 1$ atmospheres (Lind and Kok 1986). Assuming Henry equilibrium and an air concentration of $0.5 \times 10^{-9}$ atmospheres, corresponding to $0.6 \mathrm{ppb}$ volume, one obtains a melt-water concentration of $10 \mathrm{ppm}$. During the refreezing process, a certain amount of $\mathrm{H}_{2} \mathrm{O}_{2}$ is built into the ice. The exact ratio can depend on the refreezing conditions. A lower limit for this ratio $c_{\text {ice }} / c_{\text {water, }}$, which we call the partition coefficient, was determined by the following experiment: a pure single-ice crystal was produced by means of zone melting of frozen deionized water in a plexiglass cylinder of $10 \mathrm{~cm}$ diameter. The melted zone was moved along the cylinder at a velocity of $3 \mathrm{~cm}$ per day. A zone of this single crystal was again melted, $\mathrm{H}_{2} \mathrm{O}_{2}$ was injected and the zone was moved again along the cylinder. The $\mathrm{H}_{2} \mathrm{O}_{2}$ concentration of the melted zone was calculated, with an estimated melt volume of $250 \mathrm{ml}$. This value was compared to the measured $\mathrm{H}_{2} \mathrm{O}_{2}$ concentration of the ice. The partition coefficient was determined as 0.014. With a melt-water concentration of $10 \mathrm{ppm}$ and this partition coefficient, the ice concentration is calculated to be $140 \mathrm{ppb}$, which is close to the "normal" summer concentrations. However, high concentrations can be produced if $\mathrm{H}_{2} \mathrm{O}_{2}$ is trapped during refreezing, e.g. in grain boundaries.

The measured partition coefficient of 0.014 for $\mathrm{H}_{2} \mathrm{O}_{2}$ is very high compared to other trace species. In an analogous experiment with methylhydroperoxide $\left(\mathrm{CH}_{3} \mathrm{OOH}\right)$, the ice concentration was below the detection limit, which was about three orders of magnitude below the melt-water concentration. For $\mathrm{CO}_{2}$, a partition coefficient at least three orders of magnitude smaller was measured (Neftel and others 1983). We conclude from these experiments that $\mathrm{H}_{2} \mathrm{O}_{2}$ is easily built into the ice matrix.

\section{CONCLUSIONS}

Hydrogen peroxide is found to be one of the clearest seasonal tracers in both Arctic and Antarctic high-accumulation ice cores. A typical summer-to-winter ratio of 5 in the snow concentration corresponds to an atmospheric ratio of about 50. Model calculations of the

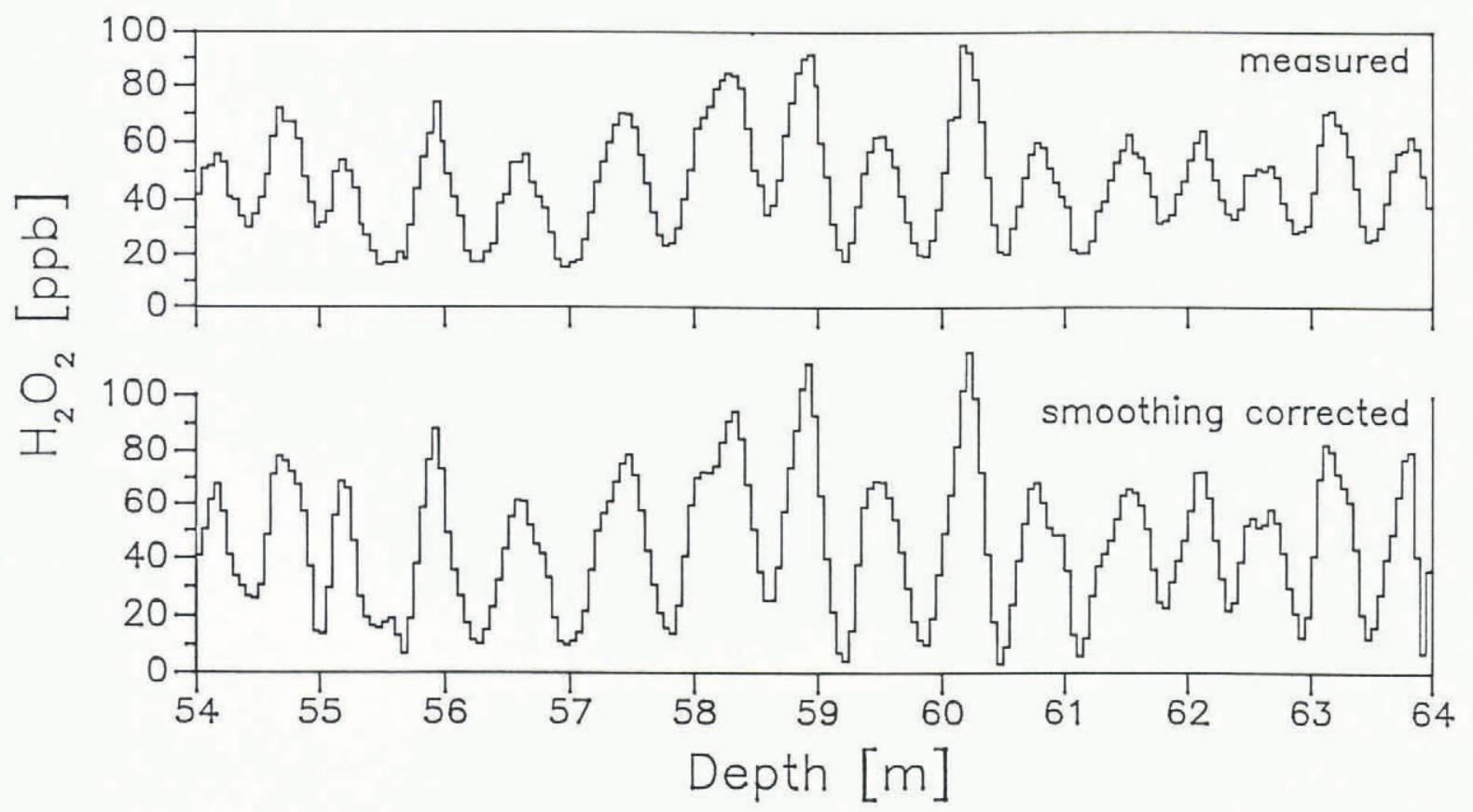

Fig.5. Deconvolution of the $\mathrm{H}_{2} \mathrm{O}_{2}$ signal in the lower firn (correction for diffusion). The diffusion length is estimated to $8 \mathrm{~cm}$ of ice. 
atmospheric $\mathrm{H}_{2} \mathrm{O}_{2}$ distribution confirm this result, and they also predict a concentration level which is in good agreement with the values derived from our in-situ measurements.

Firnification has a smoothing effect on the $\mathrm{H}_{2} \mathrm{O}_{2}$ signal. For the Siple Station record, this smoothing can be described by a diffusion length of about $8 \mathrm{~cm}$ of ice at the firn-ice transition, which is similar to that of $\delta^{18} \mathrm{O}$. The annual mean $\mathrm{H}_{2} \mathrm{O}_{2}$ concentrations of the Siple Station core exhibit large variations, but not a significant temporal trend.

The perfect seasonality, the possibility of in-situ measurements, and the small sample volume make hydrogen peroxide a very interesting parameter for ice-core dating.

\section{ACKNOWLEDGEMENTS}

We thank the PICO staff for their logistic support during drilling operations, Peter Jacob for valuable discussions and many ideas, $K$ Hänni for the $\delta^{18} \mathrm{O}$ measurements and Professor Oeschger and Professor Stauffer for continuous encouragement and support. This work was funded by COST Action 611 .

\section{REFERENCES}

Hov Ø, Isaksen I S A In press Model calculations of long-term changes in atmospheric hydroxyl, hydrogen peroxide and ozone from changes in the emissions of nitrogen oxides and methane. In Proceedings of the Fourth European Symposium on Physico-Chemical Behaviour of Atmospheric Pollutants, Stresa (Italy), 23-25 September 1986

Jacob P Unpublished. Wasserstoffperoxid in der atmosphärischen Gas- und Flüssigphasenchemie: Laborstudien und Felduntersuchungen. (PhD thesis, Universität Dortmund, 1987)

Jacob P, Tavares T M, Klockow D 1986 Methodology for the determination of gaseous hydrogen peroxide in ambient air. Fresenius' Zeitschrift für Analytische Chemie 325: $359-364$

Johnsen S J 1977 Stable isotope homogenization of polar firn and ice. International Association of Hydrological Sciences Publication 118 (General Assembly of Grenoble 1975 - Isotopes and Impurities in Snow and Ice): 210-219

Kelly T J, Daum P H, Schwartz S E 1985 Measurements of peroxides in cloudwater and rain. Journal of Geophysical Research 90(D5): 7861-7871

Klockow D, Jacob P 1986 The peroxyoxalate chemiluminescence and its application to the determination of hydrogen peroxide in precipitation. NATO Advanced Study Institute. Summer School in Chemistry of Multiphase Atmospheric Systems in Corfu. NATO ASI Ser G. Ecological Sciences 6: 117-128

Lazrus A L, Kok G L, Gitlin S N, Lind J A 1985 Automated fluorometric method for hydrogen peroxide in atmospheric precipitation. Analytical Chemistry 57(4): 917-922

Lind J A, Kok G L 1986 Henry's law determinations for aqueous solutions of hydrogen peroxide, methylhydroperoxide and peroxyacetic acid. Journal of Geophysical Research 91(D7): 7889-7895

Logan J A, Prather M J, Wofsy S C, McElroy M B 1981 Tropospheric chemistry: a global perpective. Journal of Geophysical Research 86(C8): 7210-7254

Neftel A, Oeschger H, Schwander J, Stauffer B 1983 Carbon dioxide concentration in bubbles of natural cold ice. Journal of Physical Chemistry 87(21): 4116-4120

Neftel A, Jacob P, Klockow D 1984 Measurements of hydrogen peroxide in polar ice samples. Nature 311(5981): 43-45

Neftel A, Jacob P, Klockow D 1986 Long-term record of $\mathrm{H}_{2} \mathrm{O}_{2}$ in polar ice cores. Tellus $38 \mathrm{~B}(3-4): 262-270$

Penkett S A, Jones B M R, Brice K A, Eggleton A E J 1979. The importance of atmospheric ozone and hydrogen peroxide in oxidising sulphur dioxide in cloud and rain water. Atmospheric Environment 13(1): 123-137

Schöne E 1874 Über das atmosphärische Wasserstoffhyperoxid. Berichte 7: 1693-1708
Schwander J Unpublished. Lufteinschluss im Eis in Grönland und der Antarktis. Messung der elektrischen Leitfähigkeit von Eisproben für klimatologische Anwendungen. ( $\mathrm{PhD}$ thesis, Universität Bern, 1984)

Whillans I M, Grootes P M 1985 Isotopic diffusion in cold snow and firn. Journal of Geophysical Research 90(D2): $3910-3918$ 